Article

\title{
The Impact of Foreign Trade and Urbanization on Poverty Reduction: Empirical Evidence from China
}

\author{
Xingying Wang ${ }^{1,2}$, Hongli Yan ${ }^{3, *}$, Libin $E^{4}$, Xiaoyun Huang ${ }^{2}$, Haizhen Wen ${ }^{1}$ and Yan Chen ${ }^{2}$ \\ 1 Department of Civil Engineering, Zhejiang University, Hangzhou 310058, China; \\ xying.wang@zju.edu.cn (X.W.); wenhaizhen@zju.edu.cn (H.W.) \\ 2 College of Economics, University of Guizhou, Guiyang 550025, China; xyhuang@gzu.edu.cn (X.H.); \\ ychen8@newmail.gzu.edu.cn (Y.C.) \\ 3 School of Marxism, Dongbei University of Finance \& Economics, Dalian 116025, China \\ 4 School of International Trade Dongbei, University of Finance \& Economics, Dalian 116025, China; \\ elibin@dufe.edu.cn \\ * Correspondence: yanhongli@dufe.edu.cn
}

check for updates

Citation: Wang, X.; Yan, H.; E, L.; Huang, X.; Wen, H.; Chen, Y. The Impact of Foreign Trade and Urbanization on Poverty Reduction: Empirical Evidence from China. Sustainability 2022, 14, 1464. https:// doi.org/10.3390/su14031464

Academic Editor: Tan Yigitcanlar

Received: 24 November 2021

Accepted: 12 January 2022

Published: 27 January 2022

Publisher's Note: MDPI stays neutral with regard to jurisdictional claims in published maps and institutional affiliations.

Copyright: (C) 2022 by the authors. Licensee MDPI, Basel, Switzerland. This article is an open access article distributed under the terms and conditions of the Creative Commons Attribution (CC BY) license (https:// creativecommons.org/licenses/by/ $4.0 /)$.

\begin{abstract}
Poverty eradication is a worldwide development challenge, and China's poverty reduction experience, evident in its sustainable development strategy, is receiving increasing attention. China has achieved high economic growth and success in poverty reduction over the past 40 years, since its reform and opening up. China's experience can provide lessons for other countries, however, the situation of poverty in China is still severe, and the remaining people experiencing that condition have long been in a state where income poverty, capability poverty, and intergenerational transfer of poverty coexist. This requires systematic poverty reduction in multiple fields such as the following: population, production, consumption, capital, technology, finance and taxation, education, health care and environment. Foreign trade and urbanization are the best ways to implement poverty reduction. Despite the fruitful results of international studies, the impact of foreign trade, urbanization and their synergistic effects on poverty reduction have not been fully considered. Therefore, by selecting, as panel data, the urbanization rate, foreign trade dependence, and multiple dimensions of poverty indicators of different provinces in China from 2000 to 2017, this paper establishes regression models to study the poverty reduction effects of urban and rural areas. This is accomplished by focusing on three dimensions: poverty gap; income level and gap; and the numbers of under-insurance and guaranteed expenditure, in terms of both imports and exports, respectively. The paper not only considers the synergistic effects of foreign trade and urbanization on poverty reduction, but also investigates the heterogeneity of poverty reduction effects between urban and rural areas. The research results can be applied not only to poverty reduction policy formulation in China, but they can also provide empirical lessons for other developing countries with large urban-rural disparities. Therefore, the study has important implications for both poverty reduction theory development and poverty reduction policy formulation.
\end{abstract}

Keywords: foreign trade; urbanization; poverty reduction

\section{Introduction}

Looking back at China's poverty reduction in the 21st century, two factors have been crucial: urbanization and trade liberalization, which began around the same time [1]. In October 2000, the Chinese government put forward in its proposal on the Tenth Five-Year Plan the following statement: "With the improvement of agricultural productivity and the acceleration of industrialization, the conditions for China to promote urbanization have become mature, and we should lose no opportunity to implement the urbanization strategy". China joined the World Trade Organization (WTO) on 11 December 2001, becoming the 143rd full member in the same period. Thanks to this opportunity, China's foreign trade process has been gradually accelerated. Trade liberalization has spawned 
China's economic growth, and economic growth is an essential way for a country to solve poverty [2]. Therefore, this paper will be based on an empirical analysis of the relationship between urbanization, foreign trade and poverty reduction, as well as the synergy of urbanization and foreign trade in poverty reduction.

A policy of opening to the outside world and urbanization are currently the two major engines of China's economic development. The "One Belt, One Road" initiative and new urbanization have injected new vitality into China's economic development [3]. Since the 1990s, China has vigorously promoted the economic development of poverty-stricken areas through large-scale implementation of the policy of opening up and urbanization, and the effect of poverty reduction has been prominent. International experience shows that opening to the outside world and urbanization can play a synergistic role in poverty reduction [4]. China has not yet conducted enough research on this, but it must be emphasized in the next step of formulating relevant policies on foreign trade, foreign investment, and urban development. Therefore, it is important to study the poverty reduction effects of opening up and urbanization, and give play to the mutual synergy between the two in poverty reduction, and construct a "two-wheel drive" poverty reduction strategy led by opening up and urbanization, which will serve the Chinese government and others. The national government's poverty reduction work provides a reference path.

There have been many studies on the effects of foreign trade and urbanization on poverty reduction [5]. However, due to differences in statistical calibers and measurement methods, there is no unified conclusion on the role of urbanization and foreign trade in poverty reduction. Existing studies mainly focus on the relationship between foreign trade and urbanization, the relationship between urbanization and poverty reduction, and the relationship between foreign trade and poverty reduction. These three factors are rarely included in a comprehensive analysis under a unified framework. Therefore, this paper focuses on the impact of the synergy between foreign trade and urbanization on poverty reduction. We reviewed Panudulkitti on the relationship between urbanization and poverty reduction under a closed economy [6], and expanded it innovatively by establishing a cross-synergy model of foreign trade between trade urbanization and poverty reduction under the open economy, respectively, using regional data of 27 Chinese provinces for 18 years, etc. Based on the empirical results, and drawing on successful overseas experiences, we propose the rational development of urbanization, the improvement of trade openness and the coordinated development of foreign trade urbanization, and find the domestic empirical evidence on the relationship between urbanization and poverty reduction in an open economy. We expect to achieve better poverty reduction with the synergy of foreign trade and urbanization, and provide empirical evidence for the implementation of poverty reduction strategies in other countries internationally.

\section{Literature Review}

Poverty includes both absolute poverty, where it is difficult to maintain minimum subsistence needs, and relative poverty [7], where per capita welfare is below the average level [8]. With economic and social development, the connotation of poverty is also changing, not only referring to the income problem, but also involving education, health, public services, equity and justice, personal dignity and other complex social issues [9]. According to the causes of poverty, these issues can be subdivided into income poverty, capacity poverty, resource poverty, cultural poverty, institutional poverty, intergenerational transfer poverty, etc. [10].

The international community has always been very concerned about poverty reduction. In the early days, countries generally adopted the financial aid approach to poverty reduction [11], but this tends to make people in poverty become welfare-dependent, which is not conducive to long-term poverty reduction [12]. Therefore, attention has turned to economic development to reduce poverty $[13,14]$, increasingly focusing on the education, health and public services for people in poverty [15], focusing also on issues such as capacity poverty, poverty vulnerability, equity and justice, subjective feelings and participation rights [16]. 
The economic theory of poverty reduction follows the logic of "poverty reductionincome growth-income disparity" [17]. On this basis, our paper will examine the poverty states of the study subjects in three dimensions: poverty disparity, income level and disparity, the numbers of under-insurance and protection expenditure, and measure the effect of poverty reduction.

\subsection{The Impact of Urbanization on Poverty Reduction}

Judging from the existing literature on the relationship between urbanization and poverty reduction, most studies point out that urbanization has a positive impact on poverty reduction. Awan and Shahbaz (2010) found that urbanization positively affects poverty reduction, which is particularly obvious in rural areas [18]. As the urbanization rate rises, the poverty rate will decrease. Cali and Menon (2012) studied the relevant data of India from 1983 to 1999 and found that urbanization can achieve poverty reduction in rural areas through economic linkages between urban and rural areas [19]. The literature review illuminates the following:

\subsubsection{The Main Ways to Reduce Poverty through Urbanization}

First, urbanization reduces poverty through economic growth [20,21]. Lewis (1954) [22] pointed out that economic growth can improve employment and income distribution brought about by urbanization, thereby reducing poverty. Industrial restructuring, industrial transfer, industrial agglomeration [23], and agricultural modernization brought about by urbanization have strongly promoted economic development [24]. Second, urbanization reduces poverty by affecting income levels [25]. Ahluwalia et al., (2008) showed that urbanization leads to a shift of rural labor to cities, which reduces the supply of rural labor while increasing labor productivity, leading to an increase in the income of rural residents and thus reducing poverty [26]. Third, urbanization achieves poverty reduction through its impact on employment. Mckenzie and Sasin (2007) found that the demand for products brought about by urbanization will promote enterprise development, increase labor demand for enterprises, and create more employment opportunities for the poor [27]. Fourth, urbanization achieves poverty reduction through population mobility. Christiaensen and Todo (2014) pointed out through an empirical study of cross-country data in developing countries from 1980 to 2004 that when rural poor people migrate to middle-level cities and towns compared to large cities [28], the poverty reduction effect is more effective. Fifth, infrastructure development [29] and public service [30] improvements during urbanization contribute to poverty reduction. Jayasuriya (2002) and Gordon et al., (2003) empirically examined the effects of urbanization on education [31,32]., health care, and services, and pointed out the indirect effects of urbanization on poverty reduction by improving education, health care, and services.

2.1.2. An Inverted U-Shaped Relationship between the Urbanization Rate and the Incidence of Poverty

Martinez-Vazquez et al., (2009) showed an inverted U-shaped relationship between the urbanization rate [33], and poverty incidence, i.e., urbanization has a positive effect on poverty reduction in the early stages of urbanization, whereas the effect of urbanization on poverty reduction decreases in the later stages [34]. This finding was empirically confirmed using cross-country data. It was also found that the positive effect of urbanization on poverty reduction occurs only in some countries [35].

\subsection{The Impact of Foreign Trade on Urbanization}

Moomaw and Shatter (1996) pointed out that foreign trade can directly or indirectly promote the development of urbanization through various channels, such as economic growth, industrial structure transformation, and capital accumulation [36]. Huff and Angeles (2011) pointed out that economic globalization and the strengthening of free trade have profoundly affected the urbanization patterns and processes in countries around the 
world [37], especially in Southeast Asia, many large-scale urban centers have been formed in trade-facilitated areas such as borders and the globalization index has become an essential factor influencing the urbanization of various countries [38]. However, many scholars have put forward different views, pointing out that foreign trade also has a negative effect on urbanization. Taking Mexico as an example, under the conditions of an open economy, the production links of enterprises may be transferred overseas, which is not conducive to the agglomeration of labor and capital and the development of urbanization [39]. Pengfei $\mathrm{Ni}$ and others pointed out that an unreasonable export structure and a low value-added export-oriented strategy will lead to the simultaneous existence of trade surplus and lagging urbanization development [40].

\subsection{The Impact of Foreign Trade and Urbanization on Poverty Reduction}

There are few studies that examine foreign trade, urbanization, and poverty reduction together. Daniel (2004) pointed out that foreign trade and urbanization have a mutual influence on poverty reduction [41]. Chunxiang and Zhaolong (2014) used Granger causality test methods to find a long-term equilibrium relationship between foreign trade, urbanization, and the gap between rich and poor, but did not explain the mutual influence mechanism [42]. Yongqiang and Hemao (2012) used the dual economic model to analyze the mechanism of export structure, urbanization, and the gap between urban and rural rich and poor [43]. Qilin (2011) pointed out that the demand for high-skilled labor brought about by foreign trade will exacerbate the gap between urban and rural rich and poor, while the development of urbanization will promote the transfer of surplus rural labor to employment and reduce poverty [44].

To sum up, in the context of opening up, there is a lack of systematic research on the relationship between foreign trade, urbanization, and poverty reduction. In addition, few studies have further examined the interactive effects of foreign trade, urbanization and poverty reduction. This article contains our research from this aspect.

\section{Research Methods}

\subsection{Model}

Based on our literature review, theoretical basis, and theoretical analysis, we constructed the following regression model:

$$
\begin{aligned}
& \text { Poverty }_{i t}=\alpha_{0}+\alpha_{1} \text { Urban }_{i t}+\alpha_{2} \text { Urban }^{2}{ }_{i t}+\alpha_{3} \text { Export }_{i t}+\alpha_{i} X_{i t}+v_{i}+u_{i t} \\
& \text { Poverty }_{i t}=\alpha_{0}+\alpha_{1} \text { Urban }_{i t}+\alpha_{2} \text { Urban }^{2}{ }_{i t}+\alpha_{3} \text { Import }_{i t}+\alpha_{i} X_{i t}+v_{i}+u_{i t}
\end{aligned}
$$

where Poverty Pit $_{\text {represents the poverty level, Urban }}$ it represents the level of urbanization, $U r b a n^{2}$ it represents the square term of the level of urbanization, Export ${ }_{i t}$ represents the

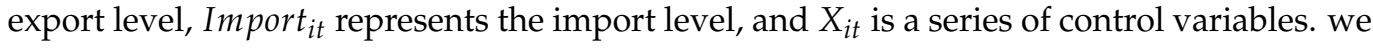
conducted GDP per capita, total railways and road transport routes as the control variables. The three indicators of length and the proportion of the added value of the financial industry in GDP reflect the indicators of income growth, fiscal expenditure, and financial development, respectively, while national fixed effects indicate random interference items.

At the same time, in order to examine the interaction between foreign trade and urbanization, the corresponding cross-terms of foreign trade indicators and urbanization were added, based on the basic model:

$$
\begin{aligned}
& \text { Poverty }_{i t}=\alpha_{0}+\alpha_{1} \text { Urban }_{i t}+\alpha_{2} \text { Urban }^{2}{ }_{i t}+\alpha_{3} \text { Export }_{i t}+\alpha_{4} \text { Export } * \text { Urban }_{i t}+\alpha_{i} X_{i t}+v_{i}+u_{i t} \\
& \text { Poverty }_{i t}=\alpha_{0}+\alpha_{1} \text { Urban }_{i t}+\alpha_{2} \text { Urban }_{i t}{ }_{i t}+\alpha_{3} \text { Import }_{i t}+\alpha_{4} \text { Import } * \text { Urban }_{i t}+\alpha_{i} X_{i t}+v_{i}+u_{i t}
\end{aligned}
$$

In order to better reflect the effect of poverty reduction and consider the sustainability of the effect of poverty reduction in the time dimension, a dynamic GMM model was selected for further analysis when analyzing the effects of urbanization and foreign trade on the population of basic subsistence allowance and basic living allowance expenditure. The dynamic models are: 


$$
\begin{aligned}
& \Delta \ln \text { Poverty }_{i t}=\alpha_{0}+\beta \text { Poverty }_{i t-1}+\alpha_{1} \text { Urban }_{i t}+\alpha_{2} \text { Urban }_{i t}{ }_{i t}+\alpha_{3} \text { Export }_{i t}+\alpha_{i} X_{i t}+v_{i}+u_{i t} \\
& \Delta \ln \text { Poverty }_{i t}=\alpha_{0}+\beta \text { Poverty }_{i t-1}+\alpha_{1} \text { Urban }_{i t}+\alpha_{2} \text { Urban }_{i t}{ }_{i t}+\alpha_{3} \text { Import }_{i t}+\alpha_{i} X_{i t}+v_{i}+u_{i t}
\end{aligned}
$$

where $\Delta \ln$ Poverty $_{i t}=\ln$ Poverty $_{i t}-\ln$ Poverty $_{i t-1}$ represents the rate of change of the poverty indicator, and Poverty it $-1_{\text {represents the poverty indicator level of the previous }}$ period. The meanings of other variables are the same as before. At the same time, in order to measure the interaction between foreign trade and urbanization, the corresponding cross-terms of foreign trade indicators and urbanization were added based on the abovementioned dynamic model, expressed as:

$$
\begin{aligned}
& \Delta \ln \text { Poverty }_{i t}=\alpha_{0}+\beta \text { Poverty }_{i t-1}+\alpha_{1} \text { Urban }_{i t}+\alpha_{2} \text { Urban }^{2}{ }_{i t} \\
& +\alpha_{3} \text { Export }_{i t}+\alpha_{4} \text { Export } * \text { Urban }_{i t}+\alpha_{i} X_{i t}+v_{i}+u_{i t} \\
& \Delta \ln \text { Poverty }_{i t}=\alpha_{0}+\beta \text { Poverty }_{i t-1}+\alpha_{1} \text { Urban }_{i t}+\alpha_{2} \text { Urban }^{2}{ }_{i t} \\
& +\alpha_{3} \text { Import }_{i t}+\alpha_{4} \text { Import } * \text { Urban }_{i t}+\alpha_{i} X_{i t}+v_{i}+u_{i t}
\end{aligned}
$$

\subsection{Variables}

\subsubsection{Dependent Variables}

In order to fully reflect the effect of poverty reduction, the explanatory variables measured the effect of poverty reduction from both urban and rural subjects, as well as from different dimensions such as poverty gap, income level and gap, number of minimum subsistence allowance and minimum guarantee expenditure.

\section{Poverty gap}

The poverty gap was measured by three indicators: poverty incidence, "Headcount"; poverty depth, "Poverty gap"; and poverty intensity, "Fgt2". The incidence of poverty reflects the size of the population in poverty-that is, the proportion of the number of people whose income is below the poverty line. The depth of poverty is the average gap between the per capita income of the poor and the poverty line, and the intensity of poverty indicates the equilibrium degree of income distribution within the poor; these two indicators reflect the average poverty level and income distribution of the poor.

To measure the poverty gap between cities and rural areas in each province in China, we had to first determine the poverty line. For the rural income data of 17 provinces from 2000 to 2017, we used the per capita net income of farmers of 2300 yuan (2010 constant price), announced by the Central Poverty Alleviation and Development Work Conference in 2011, as the national rural poverty line, and we used the rural consumer price index to establish the rural poverty line of China from 2000 to 2017. Regarding the income data of urban residents in 19 provinces from 2000 to 2017, considering that the rural poverty line announced by the Central Poverty Alleviation and Development Work Conference in 2011 is too low for urban residents, it will seriously underestimate the urban poverty situation. The average subsistence allowance for cities in the central, western, and northeastern regions is the base, and the urban poverty line from 2000 to 2017 is obtained by using the consumer price index of China. We used the POVCAL software provided by the World Bank website to estimate the incidence, depth, and intensity of poverty in urban and rural areas of each province.

2. Per capita disposable income level and urban-rural gap

To measure income level, three indicators were used: urban per capita disposable income, rural per capita disposable income, and multiples of the urban rural income gap, which are recorded as Reveurban, Rural and Timeurra, respectively. Increasing income levels is one of the most important ways to reduce poverty. The core measure of poverty reduction is still to increase the per capita disposable income of urban and rural areas. We selected data from 27 provinces from 2000 to 2017 for analysis. In order to reduce the impact of heteroscedasticity, we took the natural logarithm of the two variables of urban 
per capita disposable income and rural per capita disposable income. In addition to raising income levels, reducing income inequality is also an essential part of poverty reduction. To narrow the income gap is mainly to narrow the income gap between urban and rural areas. The selected data were analyzed by calculating the multiple personal disposable income gap between urban and rural areas.

3. Population of basic subsistence allowance and basic living allowance expenditures

Two indicators were used to measure the proportion of urban residents with basic living allowance to the total population and the proportion of rural residents with basic living allowance to the total population, recorded as "Headurban" and "Headrural", respectively. The Department of Finance of the Ministry of Civil Affairs has announced the number of urban and rural subsistence allowances and the number of rural subsistence allowance in each province since 2007. Urban and rural subsistence allowance households are typical representatives of urban poverty and rural poverty. Therefore, the number of urban and rural subsistence allowances can represent the corresponding urban and rural poverty conditions. We used the number of urban and rural residents to represent urban poverty and rural poverty, respectively. Given the data collection situation, 27 provinces from 2007 to 2016 were selected for analysis.

In addition, two indicators, the proportion of urban minimum living security expenditure to GDP and the proportion of rural minimum living security expenditure to GDP, were used to measure the living security expenditure, and the poverty level was measured from the perspective of the amount of benefits provided to the low-income earners, denoted as "Exraurban" and "Exrarural", respectively. The Department of Finance of the Ministry of Civil Affairs of China has announced the expenditures for urban minimum living security and rural minimum living security in various provinces since 2007 . The minimum living security expenditures reflect the relief and support provided by the Chinese government to the poor, and therefore also reflect the poverty situation of the corresponding urban and rural areas from fiscal expenditure. Given the data collection situation, the 2007-2016 data of 27 provinces in China were selected for analysis.

In addition to the data released by the Department of Finance of the Ministry of Civil Affairs of China, other data come from the "China Statistical Yearbook", provincial statistical yearbooks, and the National Bureau of Statistics website.

\subsubsection{Independent Variables}

\section{Urbanization level}

The ratio of urban population to total population was used to measure the level of urbanization. We calculated the ratio of the permanent urban population to the total population at the end of the year and recorded it as "Urbanratio" in the model.

\section{Level of foreign trade}

Two indicators, the proportion of exports to GDP and the proportion of imports to GDP, were used to measure the level of foreign trade, and denoted as "Expraio" and "Impratio", respectively.

\section{Other control variables}

Three indicators, namely per capita GDP, total length of railway and road transport routes, and the proportion of financial industry added value in GDP, reflect the level of regional economic development, local infrastructure, and financial development, respectively, as control variables. Among them, per capita GDP is expressed as "Pgdp"; the total length of railway and road transportation lines is expressed as Line; and the financial scale is expressed as the proportion of the added value of the financial industry in GDP, recorded as "Finaratio". To reduce the effect of heteroskedasticity, the natural logarithm was taken for the two control variables of GDP per capita and total length of rail and road transport routes. To avoid endogeneity problems, the values of the explanatory variables were taken with a one-period lag, by prefixing L1 to the variable names. 


\subsection{Descriptive Statistics}

The descriptive statistics of each variable are shown in Table 1. Among them are the following: "Headcount" represents the incidence of poverty; "Povertygap" represents the depth of poverty, taking the logarithmic value; "Fgt2" represents the poverty intensity; we added $-\mathrm{U}$ to indicate the urban indicator and - $\mathrm{R}$ to indicate the rural indicator; and "Urbanratio" indicates the proportion of the urban population to the total population. "Lnpgdp" is the logarithm of GDP per capita. "Line" is the logarithm of the total mileage of railways and highways. "Finaratio" is the proportion of the added value of the financial industry in GDP. "Expratio" is the proportion of exports to GDP. "Impratio" is the proportion of imports to GDP. "Reveurban" is the urban per capita disposable income. "Reverural" is the rural per capita disposable income. "Timeurra" is the multiple of urban-rural income gap.

Table 1. Descriptive statistical results of variables.

\begin{tabular}{cccccc}
\hline Variable & Samples & Mean & Sd. & Min. & Max \\
\hline Headcount-U & 342 & 4.934 & 6.748 & 0.000 & 39.196 \\
Povertygap-U & 342 & 1.233 & 1.822 & 0.000 & 11.193 \\
Fgt2-U & 342 & 0.525 & 0.823 & 0.000 & 4.894 \\
Headcount-R & 306 & 18.761 & 17.875 & 0.000 & 78.838 \\
Povertygap-R & 306 & 6.491 & 7.018 & 0.000 & 35.420 \\
Fgt2-R & 306 & 3.338 & 3.900 & 0.000 & 21.344 \\
Urbanratio & 486 & 45.389 & 11.212 & 19.600 & 69.850 \\
Lnpgdp & 486 & 9.898 & 0.798 & 7.887 & 11.582 \\
Line & 486 & 0.997 & 0.305 & 0.037 & 1.525 \\
Finaratio & 486 & 0.022 & 0.018 & 0.000 & 0.105 \\
Expratio & 486 & 0.129 & 0.161 & 0.011 & 0.989 \\
Impratio & 486 & 0.090 & 0.117 & 0.004 & 0.854 \\
Reveurban & 486 & 4.146 & 0.252 & 3.674 & 4.710 \\
Reverural & 486 & 3.681 & 0.289 & 3.124 & 4.397 \\
Timeurra & 486 & 2.971 & 0.590 & 1.892 & 5.103 \\
\hline
\end{tabular}

Note: -U indicates cities and towns; -R indicates rural areas.

\section{Results}

\subsection{Model Regression Results Based on Poverty Gap}

In this section, we regress the incidence of rural poverty "headcount", depth of poverty "povertygap", and poverty intensity "fgt2" in each province. Limited by the availability of data, this section includes the income data of rural residents in 17 provinces from 2000 to 2017.

\subsubsection{Regression Results of Exports, Urbanization on Poverty Gap}

First, we get the basic estimation results. In order to further examine the interaction between exports and urbanization on the poverty gap, we introduce the cross term of import and export and the level of urbanization. In order to avoid endogenous problems, we choose the one-period lagging value of the explanatory variable as the instrumental variable of this variable for analysis. The results show in Table 2.

Table 2 shows the poverty gap; for the urban poverty gap, the coefficients of urbanization on the three poverty gap indicators in towns and cities are negative, regardless of whether the cross-sectional terms are considered. The coefficients on poverty incidence and poverty depth are significant at the 1\% significant level, indicating that urbanization significantly reduces the level of poverty in towns and cities. The coefficients of the square of urbanization are all positive, and in most cases they are significant at least at the $10 \%$ significance level. This has further verified the inverted U-shaped feature of the poverty reduction effect of the level of urbanization. The two control variables of per capita GDP and the total length of railway and road transport routes also played a role in reducing the urban poverty gap. The export coefficient performance is not stable enough, and the significance level is not high. The coefficients of the cross-terms of exports and urbanization are all negative, which is consistent with the conclusion of the theoretical model, but the level of 
significance is not high. This suggests that there is much room for improvement in China's ability to leverage the interaction between exports and urbanization to reduce poverty.

For the rural poverty gap index, the coefficients of urbanization on the two poverty gap indicators, namely the incidence of poverty and the intensity of poverty, are all negative. Moreover, the coefficients of the square of urbanization are all positive, and the coefficient of the incidence of poverty is significant at $1 \%$. The poverty intensity coefficient is significant at the $5 \%$ significance level, indicating that urbanization has significantly reduced the rural poverty level, and further verified the inverted U-shaped characteristics of the poverty reduction effect of the urbanization level. Per capita GDP has not played a positive role in reducing the poverty gap in rural areas, while the total length of railway and road transport routes has played a significant role in reducing poverty, which fully validates the common assumption that better road infrastructure leads to better income in rural areas. The export coefficient is positive, but not significant. This shows that the direct impact of China's foreign exports on rural poverty reduction is limited, and there is still much room for improvement. The coefficients of urbanization and urbanization squared are consistent with the previous basic situation without considering the cross-term, showing an inverted U-shaped characteristic. Due to the addition of the cross-term, the coefficients of exports themselves become significant. The export coefficients are negative, indicating that after considering the interaction between exports and urbanization, the exports themselves have played a significant role in reducing poverty. However, the cross-term coefficients of exports and urbanization are negative; some are not significant, indicating that exports and urbanization have not yet fully played an interactive role in rural poverty reduction, and that there is substantial room for improvement.

\subsubsection{Regression Results of Imports, Urbanization on Poverty Gap}

Similar to the previous export analysis, we first obtained the basic estimation results. In order to further examine the interaction between imports and urbanization on the poverty gap, the cross-term of imports and urbanization levels is introduced. The specific results are shown in Table 3.

For the urban poverty gap, it can be seen from Table 3 that the inverted U-shaped characteristics of the poverty reduction effect of urbanization are consistent with the previous analysis. The two control variables of GDP per capita and the total length of railway and road transportation routes also had a positive effect on reducing the urban poverty gap. Before the cross-term was added, the coefficient of imports was negative. After the cross-term was added, the coefficient of the imports became positive, the performance was not stable enough, and the significance level was generally not high. The coefficients of the cross-terms of imports and urbanization are all negative, which is consistent with the conclusion of the theoretical model, but the level of significance is also not high. This shows that China also has a lot of room for improvement in the utilization of the interaction of imports and urbanization in poverty reduction. 
Table 2. Regression results of exports and, urbanization on the poverty gap.

\begin{tabular}{|c|c|c|c|c|c|c|c|c|c|c|c|c|}
\hline \multirow[b]{3}{*}{ L1.Urbanrati } & \multicolumn{6}{|c|}{ Urban Poverty Gap } & \multicolumn{6}{|c|}{ Rural Poverty Gap } \\
\hline & \multicolumn{2}{|c|}{ Headcount } & \multicolumn{2}{|c|}{ Poverty Gap } & \multicolumn{2}{|c|}{ Fgt2 } & \multicolumn{2}{|c|}{ Headcount } & \multicolumn{2}{|c|}{ Poverty Gap } & \multicolumn{2}{|c|}{ Fgt2 } \\
\hline & $-0.7991^{* * *}$ & $-0.8370^{* * *}$ & $-0.1658^{* * *}$ & $-0.1850^{* *}$ & -0.0397 & -0.0480 & $-2.9430 * * *$ & $-2.6370^{* * *}$ & 110.6780 & 1005.4260 & $-0.3590^{* *}$ & -0.2720 \\
\hline L1 Urb² & $\begin{array}{c}0.1956 \\
0.0070 \text { * }\end{array}$ & $\begin{array}{c}0.2453 \\
0.0074^{* *}\end{array}$ & $\begin{array}{c}0.0603 \\
0.00158 \text { ** }\end{array}$ & $\begin{array}{c}0.0759 \\
0.0018 \text { * }\end{array}$ & $\begin{array}{l}0.0326 \\
0.0004\end{array}$ & $\begin{array}{l}0.0409 \\
0.0005\end{array}$ & $\begin{array}{c}0.4280 \\
0.0300 * * *\end{array}$ & $\begin{array}{c}0.4870 \\
0.0250^{* * * *}\end{array}$ & $\begin{array}{r}925.7450 \\
-4.1270\end{array}$ & $\begin{array}{c}1319.7020 \\
-17.4110\end{array}$ & $\begin{array}{l}0.1600 \\
0.0020\end{array}$ & $\begin{array}{l}0.1890 \\
0.0010\end{array}$ \\
\hline & 0.0027 & 0.0034 & 0.0008 & 0.0011 & 0.0004 & 0.0006 & 0.0060 & 0.0070 & 11.2400 & 17.8280 & 0.0020 & 0.0030 \\
\hline L1.Pgdp & -0.00007 & -0.0001 & $-0.00003^{*}$ & $-0.00003 *$ & $-0.00001^{* *}$ & $-0.00001^{* *}$ & $0.0001^{* * *}$ & $0.0001^{* *}$ & 0.0100 & 0.1470 & 0.0001 * & $0.0001 * *$ \\
\hline & 0.0000 & 0.0001 & 0.0000 & 0.0000 & 0.0000 & 0.0000 & 0.0010 & 0.0000 & 0.1810 & 0.2130 & 0.0000 & 0.0000 \\
\hline L1.Line & -10.1034 & -10.0249 & -2.4429 & -2.3892 & $-0.8693^{* * *}$ & $-0.8447^{* * *}$ & -36.1430 & -37.8530 & 6269.0320 & 611.4480 & $-7.232^{* * *}$ & $-7.5040^{* * *}$ \\
\hline L1.Finaratio & $\begin{array}{c}1.5886 \\
24.7049 \\
21.3956\end{array}$ & $\begin{array}{c}1.6623 \\
26.2688 \\
21.4947\end{array}$ & $\begin{array}{l}0.4845 \\
8.3450 \\
6.6385\end{array}$ & $\begin{array}{l}0.5090 \\
8.8388 \\
6.6767\end{array}$ & $\begin{array}{c}0.2648 \\
6.2770 * \\
3.5689\end{array}$ & $\begin{array}{c}0.2772 \\
6.4849 * \\
3.5882\end{array}$ & $\begin{array}{c}3.9490 \\
7.4170 \\
41.1150\end{array}$ & $\begin{array}{c}3.8990 \\
34.9440 \\
40.5190\end{array}$ & $\begin{array}{c}7914.5720 \\
120,437.6000 \\
104,822.0000\end{array}$ & $\begin{array}{c}9535.9460 \\
107,451.6000 \\
105,408.1000\end{array}$ & $\begin{array}{c}1.4820 \\
17.0180 \\
15.6360\end{array}$ & $\begin{array}{c}1.5130 \\
18.8470 \\
15.9220\end{array}$ \\
\hline L1.Expratio & 2.2194 & 6.8797 & -0.0503 & 1.9013 & -0.2484 & 0.5402 & 0.6980 & -185.0330 & 7796.4770 & $124,700.7000$ & 1.5420 & -12.9590 \\
\hline L1.Expurban & 2.8189 & $\begin{array}{c}16.5396 \\
-0.0826 \\
0.2968\end{array}$ & 0.8577 & $\begin{array}{c}5.1303 \\
-0.0353 \\
0.0920\end{array}$ & 0.4699 & $\begin{array}{c}2.7607 \\
-0.0145 \\
0.0495\end{array}$ & 11.3480 & $\begin{array}{c}49.0040 \\
3.5310^{* * * *} \\
0.8890\end{array}$ & $23,412.1900$ & $\begin{array}{c}143,920.6000 \\
-2148.5570 \\
2543.4290\end{array}$ & 4.2570 & $\begin{array}{c}19.4390 \\
0.2570 \\
0.3520\end{array}$ \\
\hline _Cons & 36.3559 & 36.9210 & 8.0018 & 8.2513 & 2.3875 & 2.4906 & 128.7420 & 126.6030 & -7469.5450 & $-15,719.8600$ & 19.6290 & 18.4870 \\
\hline & $\begin{array}{l}3.6664 \\
323\end{array}$ & $\begin{array}{l}4.0674 \\
323\end{array}$ & $\begin{array}{c}1.1399 \\
323\end{array}$ & $\begin{array}{l}1.2656 \\
323\end{array}$ & $\begin{array}{l}0.6116 \\
323\end{array}$ & $\begin{array}{c}0.6791 \\
323\end{array}$ & $\begin{array}{c}7.0100 \\
289\end{array}$ & $\begin{array}{c}7.4270 \\
289\end{array}$ & $\begin{array}{c}17,860.7400 \\
289\end{array}$ & $\begin{array}{c}20,425.8600 \\
289\end{array}$ & $\begin{array}{l}2.6340 \\
289\end{array}$ & $\begin{array}{l}2.8750 \\
289\end{array}$ \\
\hline $\mathrm{R}^{2}$ & 0.4650 & 0.4640 & 0.3510 & 0.3520 & 0.1890 & 0.1900 & 0.6420 & 0.1700 & 0.0140 & 0.0220 & 0.1820 & 0.1700 \\
\hline
\end{tabular}


Table 3. Regression results of imports, urbanization on poverty gap.

\begin{tabular}{|c|c|c|c|c|c|c|c|c|c|c|c|c|}
\hline \multirow{3}{*}{ L1.Urbanratio } & \multicolumn{6}{|c|}{ Urban Poverty Gap } & \multicolumn{6}{|c|}{ Rural Poverty Gap } \\
\hline & \multicolumn{2}{|c|}{ Headcount } & \multicolumn{2}{|c|}{ Poverty Gap } & \multicolumn{2}{|c|}{ Fgt2 } & \multicolumn{2}{|c|}{ Headcount } & \multicolumn{2}{|c|}{ Poverty Gap } & \multicolumn{2}{|c|}{ Fgt2 } \\
\hline & $\begin{array}{c}-0.8463^{* * *} \\
0.1899\end{array}$ & $\begin{array}{c}-1.0331^{* * *} \\
0.2439\end{array}$ & $\begin{array}{c}-0.1732 \text { *** } \\
0.0583\end{array}$ & $\begin{array}{c}-0.2391 * * * \\
0.0750\end{array}$ & $\begin{array}{c}-0.0413 \\
0.0316\end{array}$ & $\begin{array}{c}-0.0649 \\
0.0403\end{array}$ & $\begin{array}{c}-2.7610^{* * * *} \\
0.3562\end{array}$ & $\begin{array}{c}-2.5375^{* * * *} \\
0.4687\end{array}$ & $\begin{array}{l}111.5321 \\
932.6657\end{array}$ & $\begin{array}{l}1016.5728 \\
1113.6003\end{array}$ & $\begin{array}{c}-0.3197 \text { ** } \\
0.1312\end{array}$ & $\begin{array}{c}-0.3215 \\
0.1635\end{array}$ \\
\hline L1.Urb ${ }^{2}$ & $\begin{array}{c}0.0084^{* * *} \\
0.0025\end{array}$ & $\begin{array}{c}0.0110^{* * *} \\
0.0034\end{array}$ & $\begin{array}{c}0.00193 \text { ** } \\
0.0008\end{array}$ & $\begin{array}{c}0.0029^{* * *} \\
0.0010\end{array}$ & $\begin{array}{l}0.0006 \\
0.0004\end{array}$ & $\begin{array}{l}0.0009 \\
0.0006\end{array}$ & $\begin{array}{c}0.0220^{* * *} \\
0.0055\end{array}$ & $\begin{array}{c}0.0239^{* * *} \\
0.0067\end{array}$ & $\begin{array}{l}-4.8112 \\
11.3629\end{array}$ & $\begin{array}{c}-15.7451 \\
19.6853\end{array}$ & $\begin{array}{l}0.0029 \\
0.0021\end{array}$ & $\begin{array}{l}0.0010 \\
0.0023\end{array}$ \\
\hline L1.Pgdp & $-0.0001 * *$ & $-0.0001^{* * *}$ & $-\underset{* * *}{0.00004}$ & $-\underset{* * *}{0.00004}$ & $-\underset{* * *}{0.00002}$ & $-\underset{* * *}{0.00002}$ & $0.0001^{* * *}$ & $0.0001^{* *}$ & 0.0092 & 0.1157 & 0.0001 * & $0.0001 * *$ \\
\hline L1.Line & $\begin{array}{c}0.0000 \\
-9.8094^{* * *}\end{array}$ & $\begin{array}{c}0.0001 \\
-9.2006^{* * *}\end{array}$ & $\begin{array}{c}0.0000 \\
-2.3962^{* * *}\end{array}$ & $\begin{array}{c}0.0000 \\
-2.1678^{* * *}\end{array}$ & $\begin{array}{c}0.0000 \\
-0.8550^{* * *}\end{array}$ & $\begin{array}{c}0.0000 \\
-0.7760^{* * *}\end{array}$ & $\begin{array}{c}0.0009 \\
-36.5532 \\
* * *\end{array}$ & $\begin{array}{c}0.0006 \\
-37.8253 \\
* * *\end{array}$ & $\begin{array}{c}0.1898 \\
6354.0012\end{array}$ & $\begin{array}{c}0.2319 \\
609.9228\end{array}$ & $\begin{array}{c}0.0000 \\
-7.2295^{* * * *}\end{array}$ & $\begin{array}{c}0.0000 \\
-7.4332^{* * *}\end{array}$ \\
\hline $\begin{array}{c}\text {-Cons } \\
\text { Samples } \\
\mathrm{R}^{2}\end{array}$ & $\begin{array}{c}36.7165 \\
3.6279 \\
323 \\
0.4670\end{array}$ & $\begin{array}{c}38.9085 \\
4.0140 \\
323 \\
0.4670\end{array}$ & $\begin{array}{c}8.0182 \\
1.1227 \\
323 \\
0.3470\end{array}$ & $\begin{array}{l}8.7699 \\
1.2423 \\
323 \\
0.3500\end{array}$ & $\begin{array}{c}2.3662 \\
0.6016 \\
323\end{array}$ & $\begin{array}{c}2.6314 \\
0.6649 \\
323 \\
0.1830\end{array}$ & $\begin{array}{c}120.6622 \\
7.3599 \\
289\end{array}$ & $\begin{array}{c}125.3605 \\
7.8436 \\
289\end{array}$ & $\begin{array}{c}-7312.3569 \\
17,786.5747 \\
289\end{array}$ & $\begin{array}{c}-15,215.1867 \\
205,321.8578 \\
289\end{array}$ & $\begin{array}{c}18.5521 \\
2.1625 \\
289\end{array}$ & $\begin{array}{c}19.1409 \\
2.6821 \\
289\end{array}$ \\
\hline $\mathrm{R}^{2}$ & 0.4670 & 0.4670 & 0.3470 & 0.3500 & 0.1780 & 0.1830 & 0.6321 & 0.1721 & 0.0141 & 0.0229 & 0.1812 & 0.1716 \\
\hline
\end{tabular}

Note: L1 represents the value of the variable lagging by one period; L2 indicates the value of the variable in the second lag period; ${ }^{*} p<0.1,{ }^{* *} p<0.05,{ }^{* * *} p<0.01$. 
For the rural poverty gap: the coefficients of urbanization on poverty incidence and poverty intensity are both negative; the coefficients of urbanization squared are both positive; the coefficients of poverty incidence are significant at the $1 \%$ significant level; and poverty intensity is at the $5 \%$ significant level. The latter indicates that urbanization significantly reduces the rural poverty level, further verifying the inverse U-shaped effect of urbanization level on poverty reduction, that is, the inverse U-shaped characteristic of the poverty reduction effect of urbanization level. GDP per capita does not contribute positively to the reduction of rural poverty gap, while the total length of rail and road transport routes plays a significant role in poverty reduction, which fully verifies the saying that "to get rich, we must first build roads" in rural areas. The coefficients of imports are positive and negative, and insignificant. This indicates that the direct impact of China's foreign trade on rural poverty reduction is limited, and there is still much room for improvement. The coefficients of urbanization and urbanization squared are in line with the previous one without the crossover term, showing an inverted U-shaped characteristic. The coefficient of imports per se becomes significant due to the inclusion of the cross term, and the coefficient of imports is positive, indicating that after considering the interaction of foreign trade and urbanization, exports per se and imports per se do not play a more significant role in poverty reduction. The coefficients of the cross term between imports and urbanization are positive and negative, some significant and some insignificant, indicating that the interaction between imports and urbanization in rural poverty reduction has not been fully exploited, and there is much room for improvement.

\subsection{Model Regression Results Based on Income Levels and Urban-Rural Income Gap}

In order to examine the impact of foreign trade and urbanization on urban per capita income, rural per capita income, and the urban-rural income gap, the first two indicators reflect the absolute income level, and the latter reflects relative income changes. The improvement of the absolute income level of urban and rural areas and the improvement of the dual economic structure of urban and rural areas are important aspects of poverty alleviation in China.

\subsubsection{Regression Results of Exports, Urbanization on Income Level and Urban-Rural Income Gap}

First, we obtained the basic estimation results. To further examine the interaction effect of exports and urbanization on the poverty gap, a cross term of exports and urbanization level was introduced. Considering that the interaction plays out with a lagged effect, one-period lagged values were added. The specific results are shown in Table 4.

It can be seen from Table 4 that the coefficients of urbanization on urban per capita disposable income and rural per capita disposable income are 0.030 and 0.044 , respectively, and they are significant at the $1 \%$ significance level, indicating that urbanization has simultaneously increased urban and rural per capita income levels, and the effect on rural areas is more potent than that in urban areas. The squares of urbanization coefficients are -0.0003 and -0.0005 , respectively, which are significant at or close to $1 \%$. This also verifies the inverted U-shaped characteristics of the poverty reduction effect of the urbanization level, that is, with the increase in the urbanization level in the initial stage, the poverty reduction effect continues to appear. However, if the level of urbanization exceeds a specific limit, further urbanization will bring new urban and rural poverty problems. The coefficients of exports are 0.146 and 0.148 , both of which are significant at the $1 \%$ significance level, indicating that exports have also played a role in increasing urban and rural incomes, and the coefficients are higher than those of urbanization. Per capita GDP, the total length of railway and road transport routes, and the added value of the financial industry accounted for the weight of GDP. These three control variables also played a positive role in increasing urban and rural incomes, and they were significant at the $1 \%$ level. They respectively reflect the vital role of regional economic growth, fiscal expenditure, and financial development to increase the income of urban and rural residents. 
Table 4. Regression results of exports and urbanization on per capita disposable income and urbanrural income gap.

\begin{tabular}{|c|c|c|c|c|c|c|}
\hline \multirow{2}{*}{ L1.Urbanratio } & \multicolumn{2}{|c|}{ Urban Per Capita Disposable Income } & \multicolumn{2}{|c|}{ Rural Per Capita Disposable Income } & \multicolumn{2}{|c|}{ Income Gap } \\
\hline & $0.0300 * * *$ & $0.0260^{* * *}$ & $0.0440 * * *$ & $0.0421^{* * *}$ & $-0.1131^{* * *}$ & $-0.1370^{* * *}$ \\
\hline & 0.0030 & 0.0030 & 0.0030 & 0.0040 & 0.0110 & 0.0140 \\
\hline \multirow[t]{2}{*}{ L1.Urb ${ }^{2}$} & $0.0010^{* * *}$ & $0.0010^{* * *}$ & $-0.0010 * * *$ & $0.0010^{* * *}$ & $0.0020^{* * *}$ & $0.0020^{* * *}$ \\
\hline & 0.0000 & 0.0000 & 0.0000 & 0.0000 & 0.0000 & 0.0000 \\
\hline \multirow[t]{2}{*}{ L1.Expratio } & $0.1460 * * *$ & $1.2560^{* * *}$ & $0.1480 * *$ & $2.3971^{* * *}$ & -0.1630 & $-9.9240 * * *$ \\
\hline & 0.0510 & 0.4300 & 0.0580 & 0.4820 & 0.2060 & 1.7300 \\
\hline \multirow[t]{2}{*}{ L1.Pgdp } & $0.0001^{* * *}$ & $0.0001^{* * *}$ & $0.0001 * * *$ & $0.0001^{* * *}$ & $0.0001^{* * *}$ & $0.0001^{* * *}$ \\
\hline & 0.0000 & 0.0000 & 0.0000 & 0.0000 & 0.0000 & 0.0000 \\
\hline \multirow[t]{2}{*}{ L1.Line } & $0.3240^{* * *}$ & $0.2821^{* * *}$ & $0.2730^{* * *}$ & $0.2250^{* * *}$ & $0.3341^{* * *}$ & $0.4120^{* * *}$ \\
\hline & 0.0250 & 0.0240 & 0.0280 & 0.0270 & 0.1010 & 0.0980 \\
\hline \multirow[t]{2}{*}{ L1.Finaratio } & $1.4710^{* * *}$ & $1.7081^{* *}$ & $2.8730 * * *$ & $2.9370^{* * *}$ & $-10.5341^{* * *}$ & $-9.400 * * *$ \\
\hline & 0.2490 & 0.2400 & 0.2830 & 0.2700 & 1.0050 & 0.9670 \\
\hline \multirow{2}{*}{$\begin{array}{c}\text { L1. } \\
\text { Expurban }\end{array}$} & & $-0.0420^{* *}$ & & $-0.0831^{* * *}$ & & $0.3680^{* * *}$ \\
\hline & & 0.0190 & & 0.0210 & & 0.0770 \\
\hline \multirow{2}{*}{$\begin{array}{c}\text { L2. } \\
\text { Expurban }\end{array}$} & & $0.0200^{* * *}$ & & $0.0231^{* * *}$ & & -0.0300 \\
\hline & & 0.0060 & & 0.0070 & & 0.0250 \\
\hline \multirow[t]{2}{*}{ L1.Expurb2 } & & 0.0001 * & & $-0.0830^{* * *}$ & & -0.0030 \\
\hline & & 0.0000 & & 0.0210 & & 0.0010 \\
\hline \multirow[t]{2}{*}{ L2.Expurb2 } & & $0.0001^{* * *}$ & & $0.0230^{* * *}$ & & 0.0010 \\
\hline & & 0.0000 & & 0.0070 & & 0.0000 \\
\hline \multirow[t]{2}{*}{ _Cons } & 2.8580 & 2.9110 & 2.1250 & 2.0920 & 5.1280 & 5.9310 \\
\hline & 0.0460 & 0.0620 & 0.0520 & 0.0700 & 0.1840 & 0.2490 \\
\hline Samples & 459 & 432 & 459 & 432 & 459 & 432 \\
\hline $\mathrm{R}^{2}$ & 0.8270 & 0.8330 & 0.8670 & 0.8750 & 0.0030 & 0.0110 \\
\hline
\end{tabular}

Note: L1 represents the value of the variable lagging by one period; L2 indicates the value of the variable in the second lag period; ${ }^{*} p<0.1,{ }^{* *} p<0.05,{ }^{* * *} p<0.01$.

When the cross-term between exports and urbanization level was introduced, the coefficients of urbanization and urbanization squared changed little compared to the basic regression results, which again verifies the inverted U-shaped characteristics of the poverty reduction effect of urbanization level. The export coefficients are 1.256 and 2.397, respectively which are significantly higher than 0.146 and 0.148 when the cross-term is not considered and are significant at the $1 \%$ significance level. The coefficients of the lagging one-period value of the cross-term of exports and urbanization are 0.020 and 0.023 , respectively, and are significant at the $1 \%$ significance level, indicating that exports and urbanization have played a synergistic effect, and urbanization with a sufficient export level is the foundation for poverty reduction. The income-increasing effect is more obvious, which is consistent with the conclusion of theoretical analysis.

In terms of urban income gap, the coefficient of urbanization on the urban-rural income gap is around -0.113 and significant at the $1 \%$ level, indicating that although urbanization raises both urban and rural per capita income levels, the effect on rural areas is stronger than that on urban areas, thus contributing to the reduction of the urban-rural income gap. The square of urbanization coefficient is 0.002 , which is also significant at the $1 \%$ significance level, indicating that the impact of urbanization level on reducing the urban-rural income gap also has an inverted U-shaped characteristic.

When the cross term of exports and urbanization level is introduced, the coefficient of exports itself is as high as -9.924 , and significant at the $1 \%$ level. The intersection of exports and urbanization does not show a significant positive impact on reducing the urban-rural income gap. On the whole, after separating the interaction between exports and urbanization, exports themselves have played an obvious positive role in reducing the urban-rural income gap. The key issue we face in the future is how to exploit the interactive role of exports and urbanization in reducing the urban-rural income gap. 
4.2.2. Regression Results of Imports, Urbanization on Income Level and Urban-Rural Income Gap

The regressions of imports and urbanization on urban disposable income per capita as well as rural disposable income and income disparity yield the basic estimation results in Table 5.

Table 5. Regression results of imports and urbanization on per capita disposable income and urbanrural income gap.

\begin{tabular}{|c|c|c|c|c|c|c|}
\hline \multirow[b]{2}{*}{ L1Urbanratio } & \multicolumn{2}{|c|}{ Urban PCDI } & \multicolumn{2}{|c|}{ Rural PCDI } & \multicolumn{2}{|c|}{ Income Gap } \\
\hline & $0.0280^{* * *}$ & $0.0260 * * *$ & $0.0420 * * *$ & $0.0381^{* * *}$ & $-0.1150^{* * *}$ & $-0.1081^{* * *}$ \\
\hline & 0.0030 & 0.0040 & 0.0030 & 0.0040 & 0.0110 & 0.0140 \\
\hline \multirow{2}{*}{$\mathrm{L}_{1} \mathrm{Urb}^{2}$} & $0.0001^{* * *}$ & $0.0001^{* * *}$ & $-0.0010^{* * *}$ & $0.0001^{* * *}$ & $0.0021^{* * *}$ & $0.0020^{* * *}$ \\
\hline & 0.0000 & 0.0000 & 0.0000 & 0.0000 & 0.0000 & 0.0000 \\
\hline \multirow[t]{2}{*}{ L1Impratio } & $0.3050^{* * *}$ & $-1.7580^{* * *}$ & $0.2700^{* * *}$ & -2.1250 & 0.2430 & 4.9910 \\
\hline & 0.0640 & 1.1580 & 0.0730 & 1.3400 & 0.2630 & 4.7520 \\
\hline \multirow[t]{2}{*}{ L1Pgdp } & $0.0001^{* * *}$ & $0.0001^{* * *}$ & $0.0001^{* * *}$ & $0.0001^{* * *}$ & $0.0001^{* * *}$ & $0.0001^{* * *}$ \\
\hline & 0.0000 & 0.0000 & 0.0000 & 0.0000 & 0.0000 & 0.0000 \\
\hline \multirow[t]{2}{*}{ L1Line } & $0.3260^{* * *}$ & $0.3001^{* * *}$ & $0.2780 * * *$ & $0.2520^{* * *}$ & $0.3001^{* * *}$ & $0.3180^{* * *}$ \\
\hline & 0.0240 & 0.0240 & 0.0280 & 0.0280 & 0.0980 & 0.1000 \\
\hline \multirow[t]{2}{*}{ L1Finaratio } & $1.5220 * * *$ & $1.8670^{* * *}$ & $2.9211^{* * *}$ & $3.1210^{* * *}$ & $-10.5420 * * *$ & $-9.4730^{* * *}$ \\
\hline & 0.2450 & 0.2490 & 0.2800 & 0.2880 & 1.0040 & 1.0220 \\
\hline \multirow[t]{2}{*}{ L1Impurban } & & 0.0580 & & 0.0790 & & -0.2130 \\
\hline & & 0.0460 & & 0.0530 & & 0.1870 \\
\hline \multirow[t]{2}{*}{ L2Impurban } & & $0.0250 * *$ & & 0.0251 * & & -0.0040 \\
\hline & & 0.0110 & & 0.0130 & & 0.0470 \\
\hline \multirow[t]{2}{*}{ L1Impurb2 } & & 0.0001 & & -0.0010 & & 0.0020 \\
\hline & & 0.0000 & & 0.0010 & & 0.0020 \\
\hline \multirow[t]{2}{*}{ L2Impurb2 } & & $0.0001^{* *}$ & & $0.0001^{* *}$ & & 0.0001 \\
\hline & & 0.0000 & & 0.0000 & & 0.0010 \\
\hline \multirow[t]{2}{*}{ _Cons } & 2.8930 & 2.9810 & 2.1560 & 2.2570 & 5.1560 & 5.1370 \\
\hline & 0.0450 & 0.0640 & 0.0520 & 0.0750 & 0.1860 & 0.2650 \\
\hline Samples & 459 & 432 & 459 & 432 & 459 & 432 \\
\hline $\mathrm{R}^{\frac{1}{2}}$ & 0.8190 & 0.8410 & 0.8690 & 0.8630 & 0.0090 & 0.0003 \\
\hline
\end{tabular}

Note. L1 represents the value of the variable lagging by one period; ${ }^{*} p<0.1,{ }^{* *} p<0.05,{ }^{* * *} p<0.01$.

As can be seen in Table 5, the coefficients of urbanization on urban and rural per capita disposable income are 0.028 and 0.042 , respectively, and are significant at the $1 \%$ significant level, which is basically consistent with the previous regression results for exports, indicating that urbanization raises both urban and rural per capita income levels, and has a stronger effect on rural than urban. The coefficients of urbanization squared are -0.0003 and -0.0005 , which are also consistent with the regression results of exports, and are also significant at or near the $1 \%$ level of significance. This verifies the inverted Ushaped characteristic of the poverty reduction effect of urbanization level. The coefficients of imports are 0.305 and 0.270 , respectively, both significant at the $1 \%$ level of significance, indicating that imports play an equal role in raising urban and rural incomes, and the coefficients are higher than those of urbanization. The three control variables of GDP per capita, total length of rail and road transport routes, and value added of the financial sector as a share of GDP also all play a positive role in contributing to the increase of urban and rural incomes.

In order to further examine the interaction between imports and urbanization to increase the per capita disposable income of urban and rural areas, the intersection of imports and urbanization levels was introduced. Considering that there is a lag effect in the interaction, the one-period lag value of the cross-term was added to the regression. The coefficients of urbanization and urbanization squared change very little relative to the basic regression results after the introduction of the cross-sectional term between imports and urbanization level, which again confirms the inverted U-shape of the poverty reduction 
effect of urbanization level. The coefficients of imports are -1.758 and -2.125 , respectively. The signs and expectations have changed. They are also different from 0.305 and 0.270 in the basic case without considering the cross-term, and they have also become insignificant. The lagging second-phase coefficients of the cross-term of imports and urbanization are 0.025 and 0.025 , respectively, and are significant at a significance level of $5 \%$ or close to $5 \%$, indicating that imports and urbanization have a strong interaction. The poverty reduction effect is more significant, which is consistent with the conclusion of the theoretical model. After comprehensively considering the introduction of the cross-term, the impact of imports itself becomes insignificant, while the impact of the cross-term is significant, indicating that the impact of imports on the per capita disposable income of urban and rural residents is mainly realized through the interaction with urbanization.

From the perspective of urban-rural income gap, the coefficient of urbanization's impact on the urban-rural income gap is around -0.113 , and is significant at a significance level of $1 \%$, indicating that although urbanization has increased both urban and rural per capita income levels, the effect on rural areas is stronger than that on cities and towns, so it is conducive to reducing the urban-rural income gap. The coefficient of urbanization squared is 0.002 , which is also significant at the $1 \%$ significance level, indicating that the impact of urbanization level on reducing the urban-rural income gap also has an inverted U-shaped characteristic. The two variables of GDP per capita and the total length of railway and road transportation routes do not reflect the characteristics of reducing the income gap between urban and rural areas, indicating that pure local economic growth and national infrastructure construction do not reflect the effect of changing the dual economic structure of urban and rural areas. The proportion of industry added value to GDP has a strong effect on reducing the urban-rural income gap, and it is significant at a significance level of $1 \%$.

From the perspective of foreign trade, the effect of imports on narrowing the urbanrural income gap is in the opposite direction and insignificant. The insignificant impact of imports on reducing the gap between urban and rural areas also shows from another side that the government should pay attention to how to guide foreign trade to better increase rural per capita income when formulating foreign trade policies, thereby reducing the income gap between urban and rural areas and achieving common prosperity.

Relative to the basic regression results, the coefficients of urbanization and urbanization squared have little change, which again verifies the inverted U-shaped characteristics of the poverty reduction effect of urbanization. The two variables of per capita GDP and the total length of railway and road transportation lines also did not reflect the characteristics of reducing the income gap between urban and rural areas, and the proportion of the added value of the financial industry in GDP still showed a strong effect on reducing the income gap between urban and rural areas.

In terms of imports, with or without the addition of the cross-sectional term and with or without considering the interaction between imports and urbanization, the effect of imports per se and the interaction between imports and urbanization on narrowing the urban-rural income gap is not significant.

Overall, when formulating foreign trade policies, the government should pay attention to how to guide foreign trade to better interact with urbanization and thus narrow the urban-rural income gap.

\subsection{Analysis Based on the Population of Basic Subsistence Allowance and the Basic Living Allowance Expenditures}

In order to fully reflect the effect of poverty reduction in urban and rural areas, the population of basic subsistence allowances in urban and rural areas as well as the basic living allowance expenditures from 2007 to 2016 in 27 provinces were selected as the explained variables for analysis. Considering the continuity of foreign trade, this section further introduces the previous period value of the explanatory variable as one of the explanatory variables for dynamic panel analysis. 
4.3.1. Regression Results of Exports and Urbanization on the Population of Basic Subsistence Allowance and the Basic Living Allowance Expenditures

Here we used the systematic GMM estimation method for empirical analysis. The explanatory variable contains the first-order lag of the explained variable, and at most, three lags of the explanatory variable were used as instrumental variables. The regression results are shown in Table 6.

Table 6. The regression results of exports and urbanization on the population of basic subsistence allowance and basic living allowance expenditures.

\begin{tabular}{|c|c|c|c|c|c|c|c|c|}
\hline \multirow[b]{2}{*}{ L1. } & \multicolumn{2}{|c|}{$\begin{array}{l}\text { U-Population of Basic } \\
\text { Subsistence Allowance }\end{array}$} & \multicolumn{2}{|c|}{$\begin{array}{l}\text { R-Population of Basic } \\
\text { Subsistence Allowance }\end{array}$} & \multicolumn{2}{|c|}{$\begin{array}{l}\text { U-Basic Living } \\
\text { Allowance Expenditures }\end{array}$} & \multicolumn{2}{|c|}{$\begin{array}{c}\text { R-Basic Living } \\
\text { Allowance Expenditures }\end{array}$} \\
\hline & $0.8959 * * *$ & $0.8952 * * *$ & $0.8296^{* * *}$ & $0.8172 * * *$ & $0.5517^{* * *}$ & $0.56215^{* * *}$ & $0.6618^{* * *}$ & $0.6891^{* * *}$ \\
\hline & 0.0117 & 0.0172 & 0.0102 & 0.0118 & 0.0194 & 0.0284 & 0.0062 & 0.0132 \\
\hline \multirow[t]{2}{*}{ Urbanratio } & $-0.0006^{* * *}$ & $-0.0004^{* * *}$ & $-0.0016^{* * *}$ & $-0.0012 * * *$ & $0.00001^{* * *}$ & $-\underset{* * *}{0.00007}$ & 0.0000 & $-\underset{* * *}{0.00005}$ \\
\hline & 0.0001 & 0.0001 & 0.0001 & 0.0001 & 0.0000 & 0.0000 & 0.0000 & 0.0000 \\
\hline \multirow{2}{*}{ Urb2 } & $0.0001^{* * *}$ & $0.0001^{* * *}$ & $0.0001 *$ & $0.00001^{* * *}$ & $0.00001^{* * *}$ & $0.00001^{* * *}$ & 0.0000 & $0.00001^{* *}$ \\
\hline & 0.0000 & 0.0000 & 0.0000 & 0.0000 & 0.0000 & 0.0000 & 0.0000 & 0.0000 \\
\hline \multirow[t]{2}{*}{ Expratio } & -0.0011 & -0.0009 & $0.0052 * *$ & $0.0127^{* * *}$ & $-0.0023^{* * *}$ & $-0.0020^{* * *}$ & $-0.0041^{* * *}$ & $-0.0047^{* * *}$ \\
\hline & 0.0008 & 0.0011 & 0.0024 & 0.0036 & 0.0002 & 0.0002 & 0.0002 & 0.0002 \\
\hline \multirow[t]{2}{*}{ Pgdp } & $0.0001^{* * *}$ & $0.0001^{* * *}$ & $0.00001^{* * *}$ & 0.00001 * & $0.00001^{* * *}$ & $0.00001^{* * *}$ & $0.00001^{* * *}$ & $0.00001^{* * *}$ \\
\hline & 0.0000 & 0.0000 & 0.0000 & 0.0000 & 0.0000 & 0.0000 & 0.0000 & 0.0000 \\
\hline \multirow[t]{2}{*}{ Line } & 0.0002 & 0.0002 & $0.0059^{* * *}$ & 0.0023 & $-0.0002^{* * *}$ & -0.0001 & $0.0002^{* * *}$ & $0.0002^{* * *}$ \\
\hline & 0.0007 & 0.0009 & 0.0012 & 0.0025 & 0.0002 & 0.0001 & 0.0000 & 0.0000 \\
\hline \multirow[t]{2}{*}{ Finaratio } & $-0.0532^{* * *}$ & $-0.0465^{* * *}$ & $-0.1181^{* * *}$ & $-0.0752^{* * *}$ & 0.0024 * & 0.0004 & $0.0131^{* * *}$ & $0.0114^{* * *}$ \\
\hline & 0.0033 & 0.0069 & 0.0120 & 0.0132 & 0.0014 & 0.0018 & 0.0008 & 0.0008 \\
\hline \multirow[t]{2}{*}{ L1.Expurban } & & $-0.0004^{* * *}$ & & $-0.0012^{* * *}$ & & $0.0001^{* * *}$ & & $0.0002^{* * *}$ \\
\hline & & 0.0001 & & 0.0001 & & 0.0000 & & 0.0000 \\
\hline \multirow[t]{2}{*}{ L1.Expurb2 } & & $-0.0004^{* * *}$ & & $0.00002 * * *$ & & $0.00001^{* * *}$ & & $0.00001^{* * *}$ \\
\hline & & 0.0001 & & 0.0000 & & 0.0000 & & 0.0000 \\
\hline \multirow[t]{2}{*}{ _Cons } & 0.0191 & 0.0166 & 0.0519 & 0.0496 & 0.0023 & 0.0027 & 0.0016 & 0.0021 \\
\hline & 0.0017 & 0.0020 & 0.0033 & 0.0016 & 0.0002 & 0.0003 & 0.0002 & 0.0003 \\
\hline sample & 243 & 243 & 243 & 243 & 243 & 243 & 243 & 243 \\
\hline Wald chi2 & $73,507.4200$ & $26,033.8500$ & $125,913.9900$ & $332,232.8300$ & 2602.5800 & 3711.3500 & $27,503.1200$ & $11,220.6700$ \\
\hline Prob $>$ chi2 & 0.0000 & 0.0000 & 0.0000 & 0.0000 & 0.0000 & 0.0000 & 0.0000 & 0.0000 \\
\hline
\end{tabular}

Note: L1 represents the value of the variable lagging by one period; U- presents Urban area; R-presents Rural area; ${ }^{*} p<0.1,{ }^{* *} p<0.05,{ }^{* * *} p<0.01$.

It can be seen from Table 6 that urbanization has a promoting effect on the decrease in the proportion of the urban population with the basic living subsistence allowance and the proportion of the rural population with the basic subsistence allowance, both of which are significant at the level of $1 \%$. The coefficient of the square term of the urbanization level is positive, indicating that the effect of urbanization on poverty reduction has an inverted U-shaped characteristic, which is the same as the previous statistical analysis conclusion. The export coefficient is negative in most cases, indicating that exports have shown a strong role in reducing urban and rural subsistence allowances and basic living allowance expenditures. After adding the interactive item of export and urbanization level, it can be seen from Table 6 that urbanization has reduced the proportion of the urban and rural subsistence allowances and the basic allowance expenditures, both of which are significant at the level of $1 \%$. The coefficient of the square term of the urbanization level is positive, indicating that the effect of urbanization on reducing urban and rural poverty has an inverted U-shaped characteristic, which is the same as the previous statistical analysis conclusion. In most cases, the export coefficient is negative, indicating that exports have shown a strong effect on reducing the urban and rural subsistence allowances and basic allowance expenditures. The lagging value of the cross-term between exports and urbanization has a significant impact on the reduction of urban and rural basic subsistence allowances, but the impact on the basic living allowance expenditure is not obvious. 
4.3.2. Regression Results of Imports and Urbanization on the Population of Basic Subsistence Allowance and Basic Living Allowance Expenditures

The regression results are shown in Table 7.

Table 7. The regression results of Imports and Urbanization on the population of basic subsistence allowance and basic living allowance expenditures.

\begin{tabular}{|c|c|c|c|c|c|c|c|c|}
\hline \multirow{3}{*}{ L1. } & \multicolumn{2}{|c|}{$\begin{array}{l}\text { U-Population of Basic } \\
\text { Subsistence Allowance }\end{array}$} & \multicolumn{2}{|c|}{$\begin{array}{l}\text { R-Population of Basic } \\
\text { Subsistence Allowance }\end{array}$} & \multicolumn{2}{|c|}{$\begin{array}{l}\text { U-Basic Living } \\
\text { Allowance Expenditures }\end{array}$} & \multicolumn{2}{|c|}{$\begin{array}{l}\text { R-Basic Living } \\
\text { Allowance Expenditures }\end{array}$} \\
\hline & $0.9099 * * *$ & $0.9066^{* * *}$ & $0.8252 * * *$ & $0.8218^{* * *}$ & $0.5888^{* * *}$ & $0.5766^{* * *}$ & $0.6522 * * *$ & $0.6375^{* * *}$ \\
\hline & 0.0134 & 0.0137 & 0.0087 & 0.0106 & 0.0210 & 0.0342 & 0.0073 & 0.0094 \\
\hline \multirow{2}{*}{ Urbanratio } & $-0.0006^{* * *}$ & $-0.0003^{* * *}$ & $-0.0018^{* * *}$ & $-0.0014^{* * *}$ & 0.0000 & 0.0000 & $0.00003 * *$ & $0.00007^{* * *}$ \\
\hline & 0.0001 & 0.0001 & 0.0001 & 0.0002 & 0.0000 & 0.0000 & 0.0000 & 0.0000 \\
\hline \multirow[t]{2}{*}{ Urb2 } & $0.00001^{* * *}$ & $0.00001 * * *$ & $0.00002^{* * *}$ & $0.00001^{* * *}$ & $0.00001 * * *$ & 0.0000 & $0.00001 * * *$ & $0.00001^{* * *}$ \\
\hline & 0.0000 & 0.0000 & 0.0000 & 0.0000 & 0.0000 & 0.0000 & 0.0000 & 0.0000 \\
\hline \multirow[t]{2}{*}{ Impratio } & 0.0012 & $0.0040 * *$ & 0.0001 & $0.0122 * * *$ & $-0.0035^{* * *}$ & $-0.0014^{* *}$ & $-0.0052^{* * *}$ & $-0.0052^{* * *}$ \\
\hline & 0.0018 & 0.0016 & 0.0047 & 0.0047 & 0.0004 & 0.0006 & 0.0012 & 0.0008 \\
\hline \multirow[t]{2}{*}{ Pgdp } & $0.00001 * * *$ & $0.00001 * * *$ & $0.00001^{* * *}$ & $0.00001^{* *}$ & $0.00001 * * *$ & $0.00001^{* * *}$ & $0.00001^{* * *}$ & 0.00001 *** \\
\hline & 0.0000 & 0.0000 & 0.0000 & 0.0000 & 0.0000 & 0.0000 & 0.0000 & 0.0000 \\
\hline \multirow{2}{*}{ Line } & 0.0003 & -0.0002 & $0.0054^{* *}$ & 0.0025 & $-0.00024^{* * *}$ & $-0.0003 *$ & 0.0001 & 0.0002 \\
\hline & 0.0006 & 0.0006 & 0.0011 & 0.0023 & 0.0002 & 0.0002 & 0.0001 & 0.0001 \\
\hline \multirow[t]{2}{*}{ Finaratio } & $-0.0510^{* * *}$ & $-0.0460 * * *$ & $-0.1245^{* * *}$ & $-0.0939^{* * *}$ & 0.0006 & 0.0000 & $0.0106^{* * *}$ & $0.0096^{* * *}$ \\
\hline & 0.0045 & 0.0053 & 0.0111 & 0.0144 & 0.0011 & 0.0013 & 0.0011 & 0.0010 \\
\hline \multirow[t]{2}{*}{ L1.Impurban } & & $-0.0009 * * *$ & & $-0.0013^{* * *}$ & & -0.00013 * & & $-0.0001^{*}$ \\
\hline & & 0.0002 & & 0.0003 & & 0.0001 & & 0.0001 \\
\hline \multirow[t]{2}{*}{ L1.Impurb2 } & & $0.00001^{* * *}$ & & $0.00002 * * *$ & & $0.00001^{* * *}$ & & $0.00001^{* * *}$ \\
\hline & & 0.0000 & & 0.0000 & & 0.0000 & & 0.0000 \\
\hline \multirow[t]{2}{*}{ _Cons } & 0.0183 & 0.0140 & 0.0583 & 0.0528 & 0.0015 & 0.0012 & $0.0007^{* *}$ & 0.0000 \\
\hline & 0.0019 & 0.0021 & 0.0022 & 0.0030 & 0.0003 & 0.0005 & 0.0003 & 0.0003 \\
\hline Samples & 243 & 243 & 243 & 243 & 243 & 243 & 243 & 243 \\
\hline Wald chi2 & $67,125.1900$ & $15,841.9300$ & $151,591.9500$ & $421,275.4900$ & 9682.2100 & $14,228.7100$ & $98,012.7700$ & $60,998.0800$ \\
\hline Prob > chi 2 & 0.0000 & 0.0000 & 0.0000 & 0.0000 & 0.0000 & 0.0000 & 0.0000 & 0.0000 \\
\hline
\end{tabular}

Note: L1 represents the value of the variable lagging by one period, ${ }^{*} p<0.1,{ }^{* *} p<0.05,{ }^{* * *} p<0.01$.

As can be seen from Table 7, the inverted U-shaped characteristics of poverty reduction in urbanization are consistent with the previous analysis. The coefficient of imports has a negative impact on the expenditures for urban and rural basic living allowances, and is significant at the level of $1 \%$, indicating that imports show a strong effect of reducing the urban and rural minimum basic living allowance expenditures. After adding the interaction item between import and urbanization level, the inverted U-shaped characteristics of poverty reduction in urbanization are consistent with the previous analysis. Imports have a positive coefficient for the urban and rural basic subsistence allowances, and a negative coefficient for the basic living allowance expenditure, which is significant at the $5 \%$ level, indicating that imports show a strong effect on reducing the expenditures for urban and rural minimum basic living allowances. The lag value of the cross-term of imports and urbanization has a significant impact on the reduction of the urban population of subsistence and the basic living allowance. expenditure.

\subsection{Regression Results Considering Regional Heterogeneity}

The "Headcount" variable of the incidence of rural poverty was selected as the poverty indicator, and the analysis was divided into three groups: eastern, central and western. In order to save space, export and import were put into a model for analysis. At the same time, in order to more fully demonstrate the role of opening to the outside world, while considering exports and imports, the use of foreign capital was also added.

4.4.1. Basic Regression Results of Foreign Trade and Urbanization on Rural Poverty Gaps in Various Regions

The basic results are shown in Table 8 . It can be seen from Table 8 that the urbanization of rural areas in eastern, central, and western China has obvious U-shaped characteristics of poverty reduction. In addition, the per capita income level in the western region has shown a strong effect on reducing poverty in rural areas, while the total length of railway and road transport lines in the eastern, central and western regions has played a significant role in reducing poverty in rural areas. The phrase "build roads 
first" applies to all regions of the country. Exports from the eastern and western regions have shown a strong effect on reducing poverty in rural areas, and imports in the central region have also shown a strong effect on reducing poverty.

Table 8. Effect of foreign trade and urbanization on rural poverty gap in different regions.

\begin{tabular}{|c|c|c|c|c|c|c|}
\hline & \multicolumn{2}{|c|}{ Eastern China } & \multicolumn{2}{|c|}{ Central China } & \multicolumn{2}{|c|}{ Western China } \\
\hline & Coef. & $p$ Value & Coef. & $p$ Value & Coef. & $p$ Value \\
\hline \multirow[t]{2}{*}{ L1.Urbanratio } & -0.707 & 0.009 & -2.140 & 0.006 & -4.399 & 0.000 \\
\hline & 0.272 & & 0.774 & & 1.257 & \\
\hline \multirow[t]{2}{*}{ L1.Urb ${ }^{2}$} & 0.007 & 0.012 & 0.024 & 0.018 & 0.052 & 0.004 \\
\hline & 0.003 & & 0.010 & & 0.018 & \\
\hline \multirow{2}{*}{ L1.Pgdp } & 0.000 & 0.001 & 0.000 & 0.001 & -0.001 & 0.002 \\
\hline & 0.000 & & 0.000 & & 0.000 & \\
\hline \multirow[t]{2}{*}{ L1.Line } & -9.671 & 0.001 & -22.873 & 0.000 & -44.633 & 0.000 \\
\hline & 2.909 & & 4.943 & & 7.178 & \\
\hline \multirow[t]{2}{*}{ L1.Finaratio } & -49.740 & 0.208 & 77.030 & 0.074 & 363.512 & 0.000 \\
\hline & 39.504 & & 43.160 & & 99.563 & \\
\hline \multirow[t]{2}{*}{ L1.Expratio } & -9.608 & 0.090 & 7.867 & 0.748 & -272.349 & 0.000 \\
\hline & 5.671 & & 24.502 & & 64.114 & \\
\hline \multirow[t]{2}{*}{ L1.Impratio } & 7.491 & 0.329 & -67.970 & 0.154 & 109.540 & 0.053 \\
\hline & 7.675 & & 47.644 & & 56.668 & \\
\hline \multirow{2}{*}{ L1.Fdiratio } & 25.089 & 0.288 & -139.250 & 0.006 & 526.330 & 0.005 \\
\hline & 23.631 & & 50.714 & & 187.029 & \\
\hline \multirow[t]{2}{*}{ _Cons } & 42.673 & 0.000 & 99.609 & 0.000 & 164.538 & 0.000 \\
\hline & 6.859 & & 13.034 & & 18.883 & \\
\hline Simple size & \multicolumn{2}{|c|}{102} & \multicolumn{2}{|c|}{85} & \multicolumn{2}{|c|}{102} \\
\hline $\mathrm{R}^{2}$ & \multicolumn{2}{|c|}{0.714} & \multicolumn{2}{|c|}{0.898} & \multicolumn{2}{|c|}{0.843} \\
\hline
\end{tabular}

Note: L1 represents the value of the variable lagging by one period.

4.4.2. Regression Results of the Effects of Interaction of Foreign Trade and Urbanization in Different Regions on Rural Poverty Reduction

After adding the cross-term of export and urbanization level, the cross-term of imports and urbanization level, and the cross-term of foreign capital utilization and urbanization level into the model, we arrived at the regression results shown in Table 9. It can be seen from Table 9 that poverty reduction through urbanization still has a strong inverted U-shaped characteristic. The per capita income level and the total length of railway and road transport routes have all played a significant role in reducing poverty. Exports from the eastern, central and western regions all show strong poverty reduction effects. Imports and urbanization have shown a strong interaction in poverty reduction, while the interaction between exports and urbanization in poverty reduction has not yet been fully realized.

\subsubsection{Summary}

On the whole, the U-shaped characteristics of urbanization and poverty reduction in rural areas in China are obvious. The per capita income level and the total length of railway and road transport routes have all played a significant role in reducing poverty. Exports from the eastern, central, and western regions all show a strong effect on reducing poverty in rural areas. Imports and urbanization show a strong interaction in rural poverty reduction, while exports and urbanization have insignificant interactions in rural poverty reduction. 
Table 9. Interactive effects of foreign trade on rural poverty reduction in different regions of China.

\begin{tabular}{|c|c|c|c|c|c|c|}
\hline & \multicolumn{2}{|c|}{ Eastern China } & \multicolumn{2}{|c|}{ Central China } & \multicolumn{2}{|c|}{ Western China } \\
\hline & Coef. & $p$ Value & Coef. & Coef. & $p$ Value & Coef. \\
\hline \multirow[t]{2}{*}{ L1.Urbanratio } & -0.887 & 0.011 & -1.610 & 0.039 & -6.207 & 0.000 \\
\hline & 0.348 & & 0.780 & & 1.314 & \\
\hline \multirow{2}{*}{ L1.Urb ${ }^{2}$} & 0.010 & 0.021 & 0.017 & 0.105 & 0.091 & 0.000 \\
\hline & 0.004 & & 0.010 & & 0.019 & \\
\hline \multirow[t]{2}{*}{ L1.Pgdp } & 0.000 & 0.000 & -0.001 & 0.000 & -0.001 & 0.000 \\
\hline & 0.000 & & 0.000 & & 0.000 & \\
\hline \multirow[t]{2}{*}{ L1.Line } & -7.996 & 0.020 & -23.155 & 0.000 & -46.100 & 0.000 \\
\hline & 3.431 & & 4.816 & & 6.717 & \\
\hline \multirow[t]{2}{*}{ L1.Finaratio } & -62.007 & 0.118 & 92.689 & 0.033 & 405.324 & 0.001 \\
\hline & 39.643 & & 43.366 & & 123.976 & \\
\hline \multirow[t]{2}{*}{ L1.Expratio } & -114.335 & 0.006 & -168.640 & 0.442 & -897.416 & 0.014 \\
\hline & 41.891 & & 219.245 & & 366.212 & \\
\hline \multirow[t]{2}{*}{ L1.Impratio } & 167.784 & 0.010 & 403.367 & 0.175 & 1452.525 & 0.000 \\
\hline & 64.875 & & 297.111 & & 293.181 & \\
\hline \multirow[t]{2}{*}{ L1.Fdiratio } & 32.863 & 0.803 & -881.715 & 0.011 & 1016.258 & 0.163 \\
\hline & 131.882 & & 348.188 & & 728.725 & \\
\hline \multirow[t]{2}{*}{ L1.Expurban } & 1.837 & 0.011 & 2.936 & 0.549 & 17.555 & 0.063 \\
\hline & 0.721 & & 4.894 & & 9.430 & \\
\hline \multirow[t]{2}{*}{ L1.Impurban } & -2.816 & 0.012 & -11.014 & 0.112 & -35.837 & 0.000 \\
\hline & 1.121 & & 6.926 & & 7.865 & \\
\hline \multirow[t]{2}{*}{ L1.Fdiurban } & -0.536 & 0.814 & 18.411 & 0.037 & -10.855 & 0.530 \\
\hline & 2.284 & & 8.849 & & 17.304 & \\
\hline \multirow[t]{2}{*}{ _Cons } & 45.650 & 0.000 & 92.258 & 0.000 & 180.294 & 0.000 \\
\hline & 7.208 & & 13.590 & & 24.798 & \\
\hline Simple size & \multicolumn{2}{|c|}{102} & \multicolumn{2}{|c|}{85} & \multicolumn{2}{|c|}{102} \\
\hline$R^{2}$ & \multicolumn{2}{|c|}{0.738} & \multicolumn{2}{|c|}{0.908} & \multicolumn{2}{|c|}{0.874} \\
\hline
\end{tabular}

Note: L1 represents the value of the variable lagging by one period.

\section{Conclusions}

The empirical analysis results based on China's interprovincial panel data show that urbanization has increased both urban and rural per capita income levels, and its effect on rural areas has been stronger than that on urban areas, thus reducing the urban-rural income gap. Moreover, the analysis results show that urbanization has significantly reduced urban and rural poverty and the proportion of urban and rural subsistence allowances. The poverty reduction effect of urbanization has an inverted U-shaped characteristic. Per capita GDP has not played a positive role in reducing the poverty gap in rural areas, while the total length of railway and road transport routes has played a significant role in reducing poverty; this fully validates the common saying that better road infrastructure leads to better income in rural areas.

Foreign trade has promoted the increase in per capita income in urban and rural areas, and its impact on rural areas is more obvious than on urban areas. Therefore, it is conducive to reducing the income gap between urban and rural areas. The impact of foreign trade on urban poverty reduction is unstable, and some of its impacts are even in the negative direction. Exports have significantly reduced rural poverty, and foreign trade has shown a strong positive effect on reducing the proportion of the urban and rural subsistence allowances and the minimum social security expenditures.

Foreign trade and urbanization have produced a strong synergistic effect in boosting income growth. Moreover, exports and urbanization have a significant interaction effect on the reduction of urban and rural subsistence allowances, and imports and urbanization have a significant effect on the reduction of urban and rural subsistence allowances. The reduction in social security expenditures has significant interactions with indicators, but exports, imports, and urbanization do not reflect significant synergy in reducing the urbanrural income gap or urban and rural poverty. These indicators also show that China 
is playing a role in foreign trade and that there is still much room for improvement in terms of the interaction between foreign trade and urbanization to jointly promote poverty reduction.

Overall, China's provincial data show that the inverted U-shaped characteristics of the poverty reduction effect of urbanization indicate that moderate urbanization is still the main poverty reduction path for some poor areas in China. However, some developed areas should also control excessive expansion of the scale of cities and towns, and consider rural revitalization. Moreover, foreign trade itself has a certain effect on poverty reduction. An interaction between foreign trade and urbanization on poverty reduction has emerged, but it has not yet been fully utilized. This reminds us how to better exercise the interactive role of foreign trade and urbanization in poverty reduction. This also reminds us from one side, how to better play the interactive role of foreign trade and urbanization in poverty reduction and promote the transformation of foreign trade from labor-intensive to knowledge-intensive or technology-intensive, thereby improving the quality of foreign trade. While other countries can learn from China on narrowing the income gap between urban and rural areas and helping to fight poverty, these are still issues that the Chinese government should focus on when formulating relevant policies in the future.

Author Contributions: Conceptualization, X.W. and H.Y.; Data curation, L.E. and X.H.; Formal analysis, L.E.; Funding acquisition, H.Y.; Investigation, X.W. and X.H.; Methodology, H.Y.; Project administration, X.H.; Resources, X.W., H.Y. and Y.C.; Software, X.W. and Y.C.; Supervision, H.Y.; Validation, H.Y. and H.W.; Writing-original draft, X.W. and H.Y.; Writing-review and editing, X.W. All authors have read and agreed to the published version of the manuscript.

Funding: This study was jointly supported by National Social Science Foundation of China (No. 20BJL071).

Institutional Review Board Statement: Not applicable.

Informed Consent Statement: Not applicable.

Data Availability Statement: The data used in this study can be obtained by contacting the corresponding author.

Conflicts of Interest: The authors declare no conflict of interest.

\section{References}

1. Anderson, G.; Ge, Y. Do Economic Reforms Accelerate Urban Growth? The Case of China. Urban Stud. 2004, 41, 2197-2210. [CrossRef]

2. Zhu, L.; He, W. China's Four-Decade Rural Poverty Reduction in Urbanization: Efforts and Outcomes. China Econ. 2019, 14, 4-13.

3. Chen, M.; Sui, Y.; Liu, W.; Liu, H.; Huang, Y. Urbanization patterns and poverty reduction: A new perspective to explore the countries along the Belt and Road. Habitat Int. 2019, 84, 1-14. [CrossRef]

4. Datt, G.; Ravallion, M.; Murgai, R. Growth, Urbanization and Poverty Reduction in India. Monash Econ. Work. $2016,1-45$.

5. Munir, K.; Ameer, A. Effect of economic growth, trade openness, urbanization, and technology on environment of Asian emerging economies. Manag. Environ. Qual. 2018, 29, 1123-1134. [CrossRef]

6. Vazquez, J.M.; Panudulkitti, P.; Timofeev, A. Urbanization and the poverty level. Rev. Estud. Reg. 2009, 1-49.

7. Ahluwalia, M.S. Income distribution and development: Some stylized facts. Am. Econ. Rev. 1976, 66, $128-135$.

8. Sen, A. Capability and Well-Being. In The Quality of Life; Sen, N., Ed.; Clarendon Press: Oxford, UK, 1993.

9. Narayan, D. Voices of the Poor: Can Anyone Hear Us? Oxford University Press: Oxford, UK, 2000; p. 356.

10. Oppenheim, C.; Harker, L. Poverty: The Facts; Child Poverty Action Group: London, UK, 1996; p. 52.

11. Tanzi, V.; Chu, K. Income Distribution and High-Quality Growth; MIT Press: Cambridge, MA, USA, 1998.

12. Gilder, G.F. Wealth and poverty. Am. J. Sociol. 1981, 11, 21.

13. Kakwani, N. Performance in living standards: An international comparison. J. Dev. Econ. 1993, 41, 307-336. [CrossRef]

14. Cord, L.; Lopez, H.; Page, J. When I Use a Word: Pro-Poor Growth and Poverty Reduction; World Bank: Washington, DC, USA, 2003.

15. Loayza, N.V.; Raddatz, C. The composition of growth matters for poverty alleviation. J. Dev. Econ. 2010, 93, 137-151. [CrossRef]

16. Jalan, J.; Ravallion, M. Transient Poverty in Post-re-Form Rural China. J. Comp. Econ. 1998, 26, 338-357. [CrossRef]

17. Li, X.; Li, L. Evaluation of China's Targeted Poverty Alleviation Policies: A Decomposition Analysis Based on the Poverty Reduction Effects. Sustainability 2021, 13, 11691. [CrossRef]

18. Awan, M.S.; Malik, N. Impact of education on poverty reduction. Int. J. Acad. Res. 2011, 33, 660-666.

19. Cai, L.S. A Review of Urbanization Poverty Reduction Theory and Its Countermeasures-Based on Analysis of Underdeveloped Regions. China For. Econ. 2019, 3, 20-22. 
20. Kanbur, R. Poverty and Development: The Human Development Report and The World Development Report; World Bank: Washington, DC, USA, 1990.

21. Agarwal, S.; Satyavada, A.; Kaushik, S.; Kumar, R. Urbanization, Urban Poverty and Health of the Urban Poor: Status, Challenges and the Way Forward. Demogr. India 2007, 36, 121-134.

22. Lewis, W.A. Economic Development with Unlimited Supplies of Labor. Manch. Sch. 2010; 22, 2, $139-191$.

23. Turok, I.; Mcgranahan, G. Urbanization and economic growth: The arguments and evidence for Africa and Asia. Environ. Urban. 2013, 25, 465-482. [CrossRef]

24. Dollar, D.; Kraay, A. Growth is Good for the Poor; Policy Research Working Paper; Paper Series 2587; The World Bank Development Research Group: Washington, DC, USA, 2000.

25. Lipi, A.I.; Hasan, N. Urbanization in Bangladesh: Emerging challenges and the way forward. Bangladesh J. Multidiscip. Sci. Res. 2021, 3, 33-44. [CrossRef]

26. Quigley, J.M. Urbanization, Agglomeration, and Economic Development; Berkeley Program on Housing \& Urban Policy, Working Paper; University of California: Berkley, CA, USA, 2008; pp. 359-367.

27. Mckenzie, D.J.; Sasin, M.J. Migration, Remittances, Poverty, and Human Capital: Conceptual and Empirical Challenges; Policy Research Working Paper; The World Bank Development Research Group: Washington, DC, USA, 2007; pp. $126-134$.

28. Christiaensen, L.; Todo, Y. Poverty Reduction during the Rural-Urban Transformation: The Role of the Missing Middle. J. World Dev. 2014, 63, 43-58. [CrossRef]

29. Agenor, P.R. A theory of infrastructure-led development. J. Econ. Dyn. Control. 2010, 34, 932-950. [CrossRef]

30. Andrés, L.; Biller, D.; Herrera Dappe, M. Reducing Poverty by Closing South Asia's Infrastructure Gap; World Bank: Washington, DC, USA, 2013.

31. Jayasuriya, R.; Wodon, Q. Explaining Country Efficiency in Improving Health and Education Indicators: The Role of Urbanization; A Background Paper for the World Development Report 2003; The World Bank: Washington, DC, USA, 2003.

32. Liu, G.G.; Wu, X.; Peng, C.; Fu, A.Z. Urbanization and Health Care in Rural China. Contemp. Econ. Policy 2003, 21, 11-24. [CrossRef]

33. Martinez-Vazquez, J.; Panudulkitti, P.; Timofeev, A. Urbanization and the Poverty Level; International Center for Public Policy Working Paper Series 2009; at AYSPS, GSU Paper 09-14; International Center for Public Policy, Andrew Young School of Policy Studies, Georgia State University: Atlanta, GA, USA, 2009.

34. Brantley, L. Urbanization and Inequality/Poverty. Urban Sci. 2017, 1, 35.

35. Imai, K.S.; Gaiha, R.; Garbero, A. Poverty Reduction during the Rural-Urban Transformation: Rural Development Is Still More Important than Urbanization? Global Development Institute Working Paper Series 2014; GDI; The University of Manchester: Manchester, UK, 2014.

36. Moomaw, R.L.; Shatter, A.M. Urbanization and Economic Development: A Bias toward Large Cities? J. Urban Econ. 1996, 40, 13-37. [CrossRef]

37. Huff, G.; Angeles, L. Globalization, Industrialization and Urbanization in Pre-World War II Southeast Asia. Explor. Econ. Hist. 2011, 48, 20-36. [CrossRef]

38. Moomaw, R.L.; Alwosabi, M.A. Urban Primacy, Gigantism, and International Trade: Evidence from Asia and the Americas; ZEI Working Papers B 20-2003; University of Bonn, ZEI-Center for European Integration Studies: Bonn, Germany, 2003.

39. Kim, Y.; Zangerling, B. Mexico Urbanization Review: Managing Spatial Growth for Productive and Livable Cities in Mexico; World Bank Publications, No. 24930; The World Bank: Washington, DC, USA, 2016.

40. Ni, P.F.; Yan, Y.G.; Zhang, A.Q. The Enigma of Under-urbanization: An Explanation Based On International Trade, Social Sciences in China. Soc. Sci. China 2015, 36, 168-185.

41. Daniel, A.T. Trade Liberalization, Labor Mobility and Wages. J. Int. Trade Econ. Dev. 2004, 13, 111-136.

42. Chunxiang, X.; Zhaolong, H. Trade opening, urbanization and urban-rural income gap in China. J. Shenyang Univ. Technol. 2014, 6, 541-547.

43. Sun, Y.Q.; Wu, H. Export Structure, Urbanization and Income Gap between Urban and Rural Residents. World Econ. 2012, 9, 105-120.

44. Qilin, M. Economic openness, urbanization level and urban-rural income gap-An empirical study based on inter-provincial panel data in China. Zhejiang Soc. Sci. 2011, 1, 11-22. 